Etikonomi

Volume 16 (2), Oktober 2017

P-ISSN: 1412-8969; E-ISSN: 2461-0771

Page 145 - 160

\title{
Attitudes of Consumers Towards Islamic and Conventional Credit Cards in Indonesia
}

\author{
Sylva Alif Rusmita ${ }^{1}$, Shochrul Rohmatul Ajija ${ }^{2}$ \\ Universitas Airlangga \\ 1'sylvarusmita@gmail.com, ${ }^{2}$ shochrul-r-a@feb.unair.ac.id
}

\begin{abstract}
This study aims to analyze the attitudes of consumers towards Islamic and conventional credit cards. Using online questionnaire survey data from 51 respondents in Surabaya, East Java, the study revealed that most consumers possessed credit cards because of their convenience factor, relationship with their existing bank, and card salesmen. Therefore, the sale is the most powerful way to invite the community to have an Islamic credit card. Many customers do not care whether their credit cards are Islamic based or not, as long as the salesman promoted cards to them and the cards are able to meet their personal needs, especially for sales and purchase transactions online, they will utilize the cards. The large number of Muslims in Surabaya should be a share of the lucrative market for Islamic credit cards. Therefore, the education about the Islamic manner of consumption and the dangers of usury should be promoted in Surabaya.
\end{abstract}

Keywords: Islamic credit card, conventional credit card, consumer's attitude

\begin{abstract}
Abstrak
Penelitian ini bertujuan untuk menganalisis sikap konsumen terbadap kartu kredit syariah dan konvensional. Dengan menggunakan data survei kuesioner online dari 51 responden di Surabaya, Jawa Timur, penelitian ini mengungkapkan babwa sebagian besar konsumen memiliki kartu kredit karena faktor kenyamanan, adanya bubungan baik dengan bank, dan adanya penawaran dari pibak pemasaran. Oleh karena itu, penjualan adalah cara paling ampuh untuk mengajak masyarakat daam memiliki kartu kredit syariah. Banyak pelanggan tidak peduli apakah kartu kredit mereka berbasis syariah atau tidak, asalkan salesman mempromosikan kartu kepada mereka dan kartu tersebut dapat memenubi kebutuban pribadi mereka terutama untuk transaksi penjualan dan pembelian secara online, mereka akan menggunakan kartu tersebut. Jumlah penduduk. Muslim yang besar di Surabaya harus menjadi bagian dari pasar yang menguntungkan untuk kartu kredit syariah. Oleb karena itu, pendidikan tentang cara konsumsi Islam dan bahaya riba harus dipromosikan di Surabaya.
\end{abstract}

Kata Kunci: kartu kredit syariah, kartu kredit konvensional, perilaku konsumen

Received: May, 11, 2017; Revised: June 21, 2017; Approved: July 10, 2017 
Attitudes of Consumers Towards

Azman Ismail, Ilyani Ranlan Rose, Rabaah Tudin, Norazryana Mat Dawi

\section{INTRODUCTION}

Islam is the way of life which brings happiness of human life for all times and places in terms of its flexibility. One of the clearest manifestations of this flexibility is in the field of transactions that is based on the "concept of permissibility in principle provided that it does not involve prohibited objects". Muslim jurists usually find no difficulty in arriving at suitable ruling on any new developments in such field. In this globalization time, the needed of sale transaction is easier than previous years ago.

Credit card is one of the easy facilitation which is provided by banks as intermediary institution. In today's society, people own credit card for many reasons. Such as, to obtain credit facility, cash advance, and easy payment. Credit card is different from a debit card that credit card does not remove money directly from user account after every transaction as it does with debit card. Credit card is different from charge card too. Charge card require from card holder to buy full amount of balance by the due date. In contrast credit card allows the card holder to arrange their payment monthly at the cost of interest.

\section{Table 1. Credit Card Issuer List in Indonesia}

\begin{tabular}{clcl}
\hline No & \multicolumn{1}{c}{ Issuer } & No & \multicolumn{1}{c}{ Issuer } \\
\hline 1 & Bank Negara Indonesia 1946 (Persero) & 13 & Bank Rakyat Indonesia (Persero) Tbk \\
2 & Bank Bukopin & 14 & Bank Permata Tbk \\
3 & Bank ICB Bumiputera, Tbk & 15 & Citibank \\
4 & Bank Central Asia, Tbk & 16 & The Hongkong \& Shanghai Bank Corp \\
5 & Bank CIMB Niaga Tbk & 17 & Bank OCBC NISP Tbk \\
6 & Bank Danamon Indonesia Tbk & 18 & Standard Chartered Bank \\
7 & Bank ICBC Indonesia & 19 & Bank UOB Indonesia \\
8 & Bank Maybank Indonesia Tbk & 20 & BNI Syariah \\
9 & Bank Mandiri (Persero) Tbk & 21 & Bank Sinarmas \\
10 & Bank Mega Tbk & 22 & AEON Credit Services \\
11 & Bank Negara Indonesia 1946 (Persero) & 23 & Bank QNB Kesawan \\
12 & PAN Indonesia Bank Ltd, Tbk & & \\
\hline
\end{tabular}

Source: Bank Indonesia (2016)

There are many types of credit card issues based on the income and the services which are provided by the companies. Standard cards are available to anyone over 18, subject to the application being accepted platinum gold or black are issue for higher credit limit and have lower interest rates. Premium are offered for people who consider to be a better credit risk, also available to people who have a specified minimum income level quit high normally. Sometime many cards offer extra benefits such as travel insurances, product guarantees and preferential loan rates. This kind of card the company will generally make a donation to the charity or affinity group with no addition charge to the cardholder. In 
Indonesia, the development of credit cards is increasing continuously. According to Bank Indonesia (2016), there are 23 credit card issuers in Indonesia as follows in Table 1.

Payment card tools in Indonesia are dominated by debit card. Total number of automated teller machine (ATM) and debit card are increasing sharply whereas the credit cards also rise but gradually from 2009 to September 2016 (See Figure 1). The transactions of credit cards in Indonesia are more active from 2009 to September 2016. The volume and value of purchase activities are rising gradually. Meanwhile, the volume and value of cash withdrawal from credit card were decreasing from 2009 to 2014 but increasing dramaticaly in 2015 (See Figure 2).

Figure 1. The Development of Payment Card Tools in Indonesia during 2009 to September 2016

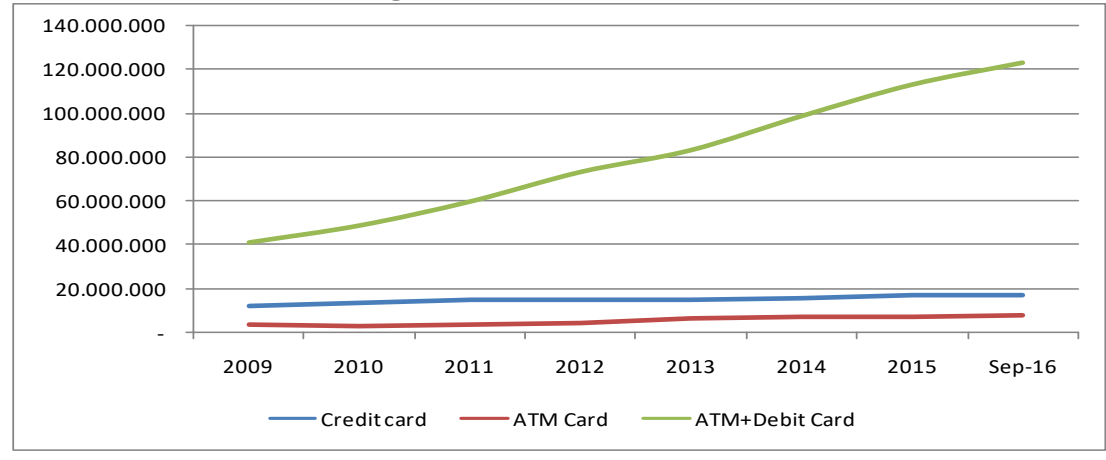

Source: Bank Indonesia (2016)

Islamic finance that has garnered tremendous interest in the face of almost two years of global economic crisis will have an important role to play come 2010. Regardless, Islamic credit card is issued by the Islamic banks especially to convenience of Muslim customers to make transactions without holding any cash on hand. It is also for security on customers behalf. Nowadays customers are more conscious about the usage of the Islamic credit cards. Not only this credit card is interest-free, but there is no profit charges if full payment is made before the due date. In Indonesia, the Islamic credit card was launched in 2007 firstly by Bank Danamon Syariah, namely Dirham Card (Ferdian, et all, 2008). Today, due to the incresing of demand, there are several Islamic credit cards launched behind the pioener i.e. BNI Syariah Hasanah Card and CIMB Niaga Master Card Syariah.

Recently, severall studies focused on ascertaining factors affacting to select Islamic credit card have been conducted globally. Choo et. al (2007) and Yee et. al (2007) analyzed the consumer choice of Islamic based credit card in Malaysia using bivariate probit model. Hussin (2011) investigated the attitudes to Islamic and conventional credit cards in Malaysia using impact analysis. Hanudin (2012) explained intention to use the Islamic credit 
Attitudes of Consumers Towards

Azman Ismail, Ilyani Ranlan Rose, Rabaah Tudin, Norazryana Mat Dawi

card in Malaysia using theory of reasoned action (TRA). Moreover, Ali and Raza (2015) studied factor affecting to select Islamic credit cards in Pakistan using TRA model.

Figure 2. The Development of Credit Card Transactions in Indonesia during 2009 to September 2016

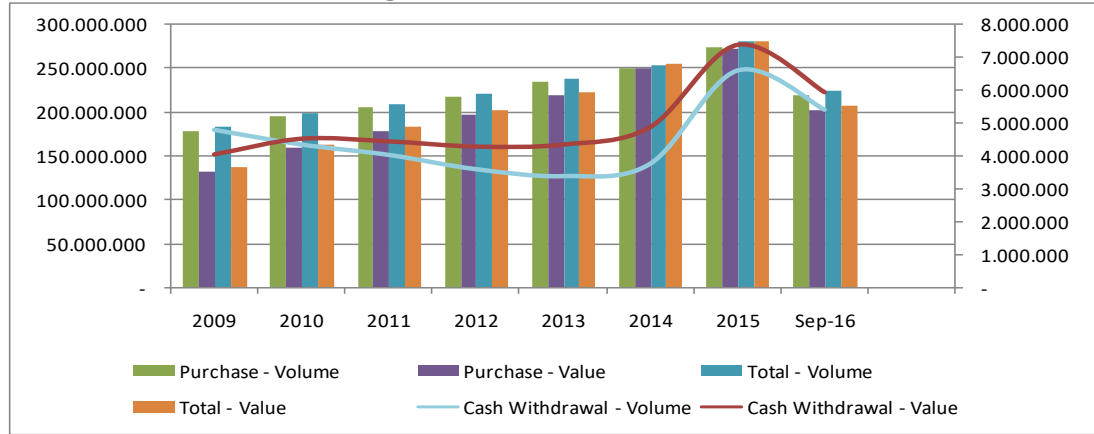

Source: Bank Indonesia (2016)

Analysis about the attitudes of consumers towards the credit cards is important in order to determine the direction of credit card market penetration development strategy in Indonesia. Since Islamic credit card products also experienced a significant development, this study aims to investigate both types of credit cards, i.e. conventional and Islamic credit cards. The structure of this paper is as follow: section 2 defines research methods, section 3 represents results and estimations while section 4 concludes the study and gives recommendations.

\section{METHOD}

The respondents of this study were credit card customers, both Islamic and conventional credit cards, in Surabaya, East Java, Indonesia. The reason of choosing Surabaya as a case study was because Surabaya is the second largest capital cities in Indonesia after Jakarta (See Figure 3). In addition, the penetration of credit card in Surabaya was the fouth highest after Makasar, Jakarta, and Banjarmasin respectively.

Figure 3. Credit Card Ownership in Indonesia 2012

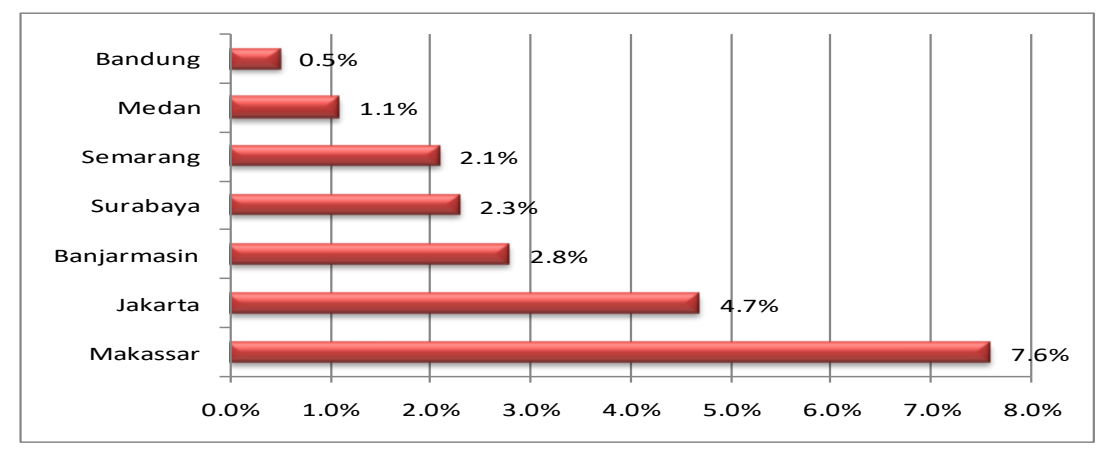

Source: MARS (2013) 
According to Ramayah et al (2003; 2006), non probability sampling could be applied since the fact that Bank and Financial Institutions Act did not allow the disclosure of such information. The questionnaires was adopted from Hussin (2011). Using 90percent confidence level and 10percent margin of error in Survey Monkey sample size calculator, the sample size of the study was 68 credit card customers in Surabaya city. The online questionnaires through google form published through social media and email were conducted to get the information from the respondents. However, the answer of respondents attained was only 51.

In order to investigate the attitudes of consumers towards Islamic and conventional credit cards in Surabaya, this study used descriptive statistics from the questionnaire results. Moreover, independent t-test was utilized to compare the means of factors influencing Islamic and conventional credit card of each sub-indicators as following equation:

$$
t_{i}=\frac{\bar{x}_{1 i}-\bar{x}_{2 i}}{\sqrt{\frac{s_{11}^{2}}{n_{1 i}}+\frac{s_{2 i}^{2}}{n_{2 i}}}}
$$

where $t$ is calculation of $t$ statistic, $i$ is sub-indicator, $\bar{x}$ is a sample mean, $n$ is a number of sample, 1 represents perception of Islamic credit card cunsumers, 2 represents perception of conventional credit card cunsomers, and $s$ represents the standard deviation (Lind, 2008).

\section{RESULT AND DISCUSSION}

This part explains the demographic background of credit card respondents in Surabaya. The components included were gender, age, marital status, number of children/dependents, status in the family (head of the family or not), religion, education, income, employment sector, occupation, the ownership of a car and housing loan.

Table 2. Demographic Characteristic of Responden

\begin{tabular}{llccllcc}
\hline \multicolumn{2}{c}{ Components } & Freq & $\mathbf{\%}$ & & Components & Freq & $\mathbf{\%}$ \\
\hline Gender & Male & 25 & 49.0 & Head & Yes & 21 & 41.2 \\
& Female & 26 & 51.0 & & No & 30 & 58.8 \\
Age & $21-30$ & 22 & 43.1 & Education & Diploma & 4 & 7.8 \\
& $31-40$ & 11 & 21.6 & & Bachelor & 28 & 54.9 \\
& $41-50$ & 15 & 29.4 & & Master & 17 & 33.3 \\
\multirow{4}{*}{ Marrital } & $51-60$ & 3 & 5.9 & & Doctoral & 2 & 3.9 \\
Status & Single & 13 & 25.5 & Monthly & $1-5$ million rupiah & 11 & 21.6 \\
& Married & 37 & 72.5 & & $5-10$ million rupiah & 20 & 39.2 \\
& Widow & 1 & 2.0 & & $10-15$ million rupiah & 16 & 31.4
\end{tabular}




\begin{tabular}{|c|c|c|c|c|c|c|c|}
\hline \multicolumn{2}{|c|}{ Components } & \multirow[t]{2}{*}{ Freq } & \multirow[t]{2}{*}{$\%$} & \multicolumn{2}{|r|}{ Components } & \multirow{2}{*}{$\begin{array}{c}\text { Freq } \\
4\end{array}$} & \multirow{2}{*}{\begin{tabular}{r|}
$\%$ \\
8.0
\end{tabular}} \\
\hline \multirow{4}{*}{$\begin{array}{l}\text { The } \\
\text { Number of } \\
\text { Children }\end{array}$} & & & & & $\begin{array}{l}\text { more than } 15 \text { million } \\
\text { rupiah }\end{array}$ & & \\
\hline & None & 19 & 37.3 & Occupation & $\begin{array}{l}\text { Government / Public } \\
\text { Sector }\end{array}$ & 20 & 39.2 \\
\hline & $<=2$ & 24 & 47.0 & & Private Sector & 23 & 45.1 \\
\hline & $>2$ & 8 & 15.7 & & Self-employment & 8 & 15.7 \\
\hline
\end{tabular}

Table 2 showed that all gender both men and women could have credit card, although most woman are credit cards holder but the gap is not to high between man and woman. It is only 2 percent, while male 49 percent and woman 51 percent. Based on age, credit card holders who have age around 21-30 years is about 43.1 percent.

According to data, consumers who have been married dominated 72.5 percent status marriage of credit card holder and 47 percent have children, at least 1 until 2 child. For the customers who have family credit card give more beneficiaries. The main benefit to the cardholder is convenience. Compared to debit cards and checks, a credit card allows small short-term loans to be quickly made to a cardholder who need not calculate a balance remaining before every transaction, provided the total charges do not exceed the maximum credit line for the card. Credit cards also offer protection. Many credit cards offer rewards and benefits packages, such as enhanced product warranties at no cost, free loss/damage coverage on new purchases, various insurance protections, for example, rental car insurance, common carrier accident protection, and travel medical insurance. So that is why most of credit cards holder was marriage.

In terms of consumer education, most customers have bachelor education level. It is dominate around 54.9 percent while the penetration of customer that have higher education like master degree around 33.3 percent. Majority, the income of credit card holders between 5-10 million per month which is 39.2 percent, and credit card holders who had higher income around 10-15 million is 31.4 percent. The analysis of income level is necessary since income was the most signficant factor influencing the use of Islamic credit card (Mansoor and Che Mat, 2009). In addition, based on occupation, mostly credit card holders are work in private sector rather than in government/public sector. 
Table 3. Credit Card Profile

\begin{tabular}{|c|c|c|c|c|c|c|c|}
\hline \multicolumn{2}{|c|}{ Components } & \multirow{2}{*}{$\frac{\text { Freq }}{21}$} & \multirow{2}{*}{$\frac{\%}{41.2}$} & \multicolumn{2}{|r|}{ Components } & \multirow{2}{*}{$\frac{\text { Freq }}{6}$} & \multirow{2}{*}{$\begin{array}{l}\% \\
6.5\end{array}$} \\
\hline Credit Card & 1 & & & Credit & Standar Cartered & & \\
\hline number & 2 & 17 & 33.3 & Card & BRI & 5 & 5.4 \\
\hline & 3 & 5 & 9.8 & Issuers & Bukopin & 5 & 5.4 \\
\hline & 4 & 8 & 15.7 & & ANZ & 4 & 4.3 \\
\hline \multirow{4}{*}{$\begin{array}{l}\text { Credit Card } \\
\text { Brand }\end{array}$} & Visa & 39 & 51.3 & & Permata & 4 & 4.3 \\
\hline & $\begin{array}{l}\text { Master } \\
\text { Card }\end{array}$ & 35 & 46.1 & & CIMB Niaga & 3 & 3.3 \\
\hline & $\begin{array}{l}\text { American } \\
\text { Express }\end{array}$ & 1 & 1.3 & & Danamon & 3 & 3.3 \\
\hline & $\begin{array}{l}\text { BCA Every } \\
\text { Day Card }\end{array}$ & 1 & 1.3 & & BNI Syariah & 2 & 2.2 \\
\hline Credit Card & $\mathrm{BNI}$ & 14 & 15.2 & & $\mathrm{UOB}$ & 2 & 2.2 \\
\hline \multirow[t]{5}{*}{ Issuers } & Mandiri & 14 & 15.2 & & Commerce Bank & 1 & 1.1 \\
\hline & $\mathrm{BCA}$ & 11 & 12.0 & & Maybank & 1 & 1.1 \\
\hline & Mega & 10 & 10.9 & & Sinarmas & 1 & 1.1 \\
\hline & Citibank & 6 & 6.5 & Holding & Islamic Credit Card & 6 & 6.5 \\
\hline & & & & Type & $\begin{array}{l}\text { Conventional Credit } \\
\text { Card }\end{array}$ & 47 & 51.1 \\
\hline
\end{tabular}

In Indonesia there are several banks that issued the credit card, both Islamic credit card and conventional credit card. All credit card that issued through bank in Indonesia should be able to accept in all over the country. As for profile credit card based on the research is as Table 3. Based on data in Table 3, credit card holders could have more than one credit card. It is based on the financial ability of credit card holders. Credit card holders who have only one credit card as much as 41 percent and the customers who have more than one cards around 58.8 percent ( 2 to 4 cards). That is mean if the customer have high financial income, they could open more than one credit card, or they could increase the financial limit of cards. Data credit card provider shows that 51.3 percent providers credit cards in Surabaya was dominated by a visa and master card 46.1 percent. It is not surprise because the two providers have domination in market since they are the largest credit card provider in the world.

Bank issuers of credit card in Indonesia were 17 banks, both public and private bank. Two government banks dominated bank issuer of credit card; they were BNI and Mandiri Bank each 15.2 percent. Then for private Bank was dominated by BCA (12 percent), Mega Bank (10.95 percent), Citibank and Standards Cartered (6.5 percent), while others 5-1 percent. The data shows that Islamic credit card was hold by 6 people form 51 sample or 11.3 percent only and conventional credit cards of 88.7 percent. From the data above the opportunities to offering Islamic credit card is still wide open. 
Attitudes of Consumers Towards

Azman Ismail, Ilyani Ranlan Rose, Rabaah Tudin, Norazryana Mat Dawi

From all 17 Bank, they are only one bank that is Islamic Bank; so Islamic credit cards product is very rare in the market. Based on table Islamic credit card holders only 2.2 percent, and the customer who chose Islamic credit cards is the customer who understand about Riba, Islamic finance and Islamic product.

The market she of Islamic credit cards is very small, this is not surprise because BNI syariah is the only one Islamic bank that issued the Islamic credit card in Indonesia. Actually the other bank also issues Islamic credit card such as Danamon Bank and Cimb Niaga Bank. The problem is the product is still list under conventional bank even though it is offered through syariah business unit under Conventional Bank such as Danamon Bank and CIMB Niaga Bank. So that two bank issues two type of a card, which is Conventional Credit Cards and Islamic Credit Cards.

The ways of Islamic credit card work is similar to conventional credit card. Cardholders can use it to shopping and meet certain needs. The working of Islamic credit card is governed Dewan Syariah Nasional (DSN) on Fatwa Number 54/DSNMUI/X/2006 about Syariah Card. According to the fatwa Islamic credit cards also imposes some tuition fee, they are: (1) Membership fee; (2) Merchant fee. This is given by merchant to the issuer cards based on the transaction of cards as ujrab; (3) Fee of cash withdrawal; (4) Compensation fee as a expenses that should paid by Bank because the cards holders was late to pay bills (over due payment)' (5) Fee of late charge payment (Taqwid). This penalty will be recognized as a social fund. If a conventional credit card could have interest as a profit of credit cards, while the Islamic credit card issuing fee as the profit of Islamic credit cards from price of goods or services transaction as a reward / compensation (ujrah).

Before the respondents were asked some factors influencing credit card selection, they were investigated about the most important factor in possessing a credit card. Most of respondents answered that the primary factors were as follows respectively: (a) personal preference because of convenience factor (19.6 percent); (b) relationship with the existing bank (19.6 percent); (c) card salesmen (13.7 percent); (d) personal preference because of financial reasons (11.8 percent); (e) work environment (11.8 percent); (f) for online shop (7.8 percent); (g) family and friends (5.9 percent); (h) general card advertisements such as newspapers, television, internet, pamphlets (5.9 percent); and (i) travelling (3.9 percent).

Interestingly, from six respondents holding the Islamic credit cards, they possessed the credit cards due to the relationship with the existing bank. There was only one respondent who had credit card because of the convenience factor. This evidence was 
reaffirmed by the findings stated that most customers choose credit cards due to a promotion.

The promotion of credit cards is very intense in Indonesia, promos and discounts are the two things that often become a reason for someone to go shopping using credit cards. It is also a particular concern for the credit card issuing bank to spend a lot of cooperation programs with certain retailers and deal making in the form of discounts, or promos for credit card users. Many credit cards in collaboration with the brand and certain supermarket (the co-brand) that offers many rebates and discounts for users of credit cards. For credit cards holders it will save a lot of monthly money expenditure and the cost of other needs (See Table 4).

The second factor that most affects the person has a credit card is traveling facility. For someone who travels frequently, having a credit card is a right thing, because credit cards can be accepted anywhere in the country for all kinds of transactions, as well as Islamic credit card must accept throughout the country. While the other factors that affect customers has a credit card is convenience and safety.

In fact, having a credit card will make cardholders feel more comfortable, especially it can be accepted anywhere, locally and abroad, so it is making transactions easier. Such as for entail huge transaction but still within the limit of the card, and the payment could be anywhere, with a detailed bill, and of course credit cards holders can saves more time because they no need to pay at bank, they could pay at home.

\section{Table 4. Factors Influencing Credit Card Selection}

\begin{tabular}{|c|c|c|c|c|c|c|c|}
\hline \multirow{3}{*}{ Factors } & & & \multicolumn{5}{|c|}{$\begin{array}{l}\text { Comparing Means between Islamic } \\
\text { and Conventional Credit Card }\end{array}$} \\
\hline & \multirow{2}{*}{\multicolumn{2}{|c|}{ Mean }} & \multicolumn{2}{|c|}{ Levene's Test } & \multicolumn{3}{|c|}{$\begin{array}{l}\text { t-test for equality of } \\
\text { means }\end{array}$} \\
\hline & & & C & Sig. & t-test & df & Sig. \\
\hline \multicolumn{8}{|l|}{ Convenience } \\
\hline (a1) Wide acceptance locally & 4.1 & 3.8 & 3.8 & 0.1 & 1.2 & 49.0 & 0.2 \\
\hline (a2) Wide acceptance abroad & 3.3 & & 29.4 & 0.0 & $(2.9)$ & 51.0 & 0.0 \\
\hline $\begin{array}{l}\text { (a3) Internet purchases and online } \\
\text { payment }\end{array}$ & 3.3 & & 34.5 & 0.0 & $(2.5)$ & 51.0 & 0.0 \\
\hline $\begin{array}{l}\text { (a4) Useful for large price/ticket } \\
\text { transactions }\end{array}$ & 4.3 & & 1.1 & 0.3 & 0.5 & 49.0 & 0.6 \\
\hline \multicolumn{8}{|l|}{ Protection } \\
\hline (b1) Safer to carry than cash & 4.0 & 3.8 & 0.7 & 0.4 & $(0.7)$ & 49.0 & 0.5 \\
\hline $\begin{array}{l}\text { (b2) Insurance provision when } \\
\text { traveling }\end{array}$ & 3.8 & & 2.1 & 0.2 & 0.4 & 49.0 & 0.7 \\
\hline $\begin{array}{l}\text { (b3) Protection against loss or } \\
\text { defects of products purchased } \\
\text { using card }\end{array}$ & 3.2 & & 9.9 & 0.0 & $(3.7)$ & 51.0 & 0.0 \\
\hline
\end{tabular}




\begin{tabular}{|c|c|c|c|c|c|c|c|}
\hline \multirow{3}{*}{ Factors } & \multirow{3}{*}{\multicolumn{2}{|c|}{ Mean }} & \multicolumn{5}{|c|}{$\begin{array}{l}\text { Comparing Means between Islamic } \\
\text { and Conventional Credit Card }\end{array}$} \\
\hline & & & \multicolumn{2}{|c|}{ Levene's Test } & \multicolumn{3}{|c|}{$\begin{array}{l}\text { t-test for equality of } \\
\text { means }\end{array}$} \\
\hline & & & C & Sig. & t-test & df & Sig. \\
\hline $\begin{array}{l}\text { (b4) Protection when card is lost or } \\
\text { stolen }\end{array}$ & 4.2 & & 10.6 & 0.0 & $(0.5)$ & 49.0 & 0.6 \\
\hline \multicolumn{8}{|l|}{ Flexibility } \\
\hline $\begin{array}{l}\text { (c1) Automatic payment in full by } \\
\text { direct debit from bank account }\end{array}$ & 3.1 & 3.3 & 4.0 & 0.1 & $(2.1)$ & 51.0 & 0.0 \\
\hline $\begin{array}{l}\text { (c2) Zero interest installment } \\
\text { facilities }\end{array}$ & 3.4 & & 15.9 & 0.0 & $(2.9)$ & 51.0 & 0.0 \\
\hline $\begin{array}{l}\text { (c3) Facilitates paying bills } \\
\text { electronically and access to } \\
\text { statement }\end{array}$ & 3.6 & & 36.3 & 0.0 & $(4.7)$ & 51.0 & 0.0 \\
\hline $\begin{array}{l}\text { (c4) Availability of supplementary } \\
\text { cards }\end{array}$ & 3.3 & & 4.7 & 0.0 & 1.1 & 49.0 & 0.3 \\
\hline \multicolumn{8}{|l|}{ Finance } \\
\hline $\begin{array}{l}\text { (d1) Short-term credit without } \\
\text { charge }\end{array}$ & 4.0 & 3.4 & 0.0 & 0.9 & $(0.9)$ & 49.0 & 0.3 \\
\hline (d2) Provides immediate credit & 3.7 & & 0.1 & 0.8 & $(0.3)$ & 49.0 & 0.7 \\
\hline (d3) Possibility of cash advance & 2.6 & & 0.8 & 0.4 & $(1.8)$ & 51.0 & 0.1 \\
\hline (d4) 0 joining or annual fee & 3.5 & & 24.5 & 0.0 & $(1.9)$ & 51.0 & 0.1 \\
\hline $\begin{array}{l}\text { (d5) Paying debt according to } \\
\text { budget/affordability }\end{array}$ & 3.2 & & 15.1 & 0.0 & $(2.0)$ & 51.0 & 0.1 \\
\hline \multicolumn{8}{|l|}{ Promotion } \\
\hline $\begin{array}{l}\text { (e1) Special discounts in selected } \\
\text { outlets }\end{array}$ & 4.3 & 4.1 & 1.2 & 0.3 & 0.5 & 49.0 & 0.6 \\
\hline $\begin{array}{l}\text { (e2) Road show with instant } \\
\text { application approval or gift } \\
\text { promotion }\end{array}$ & 3.9 & & 0.3 & 0.6 & $(0.2)$ & 49.0 & 0.8 \\
\hline (e3) Bonus and rewards & 4.2 & & 2.6 & 0.1 & 0.1 & 49.0 & 0.9 \\
\hline \multicolumn{8}{|l|}{ Travel Economics } \\
\hline $\begin{array}{l}\text { (f1) Commission free traveler's } \\
\text { cheques }\end{array}$ & 4.1 & 4.0 & 1.7 & 0.2 & 0.6 & 49.0 & 0.5 \\
\hline $\begin{array}{l}\text { (f2) } 0 \text { deposit is required for car } \\
\text { hire }\end{array}$ & 3.9 & & 4.0 & 0.1 & 0.6 & 49.0 & 0.6 \\
\hline \multicolumn{8}{|l|}{ Reputation } \\
\hline (g1) Status symbol & 3.7 & 3.7 & 0.0 & 0.8 & $(0.8)$ & 49.0 & 0.4 \\
\hline $\begin{array}{l}\text { (g2) Credit card company such as } \\
\text { Visa,MasterCard }\end{array}$ & 4.3 & & 1.3 & 0.3 & $(2.1)$ & 49.0 & 0.0 \\
\hline $\begin{array}{l}\text { (g3) 1 slamic Credit card brand } \\
\text { name such as Danamon S1 riah, } \\
\text { BNI S1 riah Hasanah Card and } \\
\text { CIMB Niaga MasterCard S1 riah } \\
\text { (g4) Reputation of card issuers }\end{array}$ & 3.5 & & 5.0 & 0.0 & 2.1 & 49.0 & 0.0 \\
\hline $\begin{array}{l}\text { such as Danamon, BNI, and CIMB } \\
\text { Niaga }\end{array}$ & 3.7 & & 3.3 & 0.1 & 1.4 & 49.0 & 0.2 \\
\hline (g5) Reputation of Shari'ah board & 3.5 & & 1.0 & 0.3 & 1.2 & 49.0 & 0.2 \\
\hline
\end{tabular}

In terms of credit card security there is no doubt, because usually credit cards also offer additional amenities as well as protection such as travel insurance or any other word. 
Provide protection to cardholders in term of goods purchased is not in line with expectations or damaged. However, the most important thing is credit card holder does not need to carry cash. Generally, factors influencing credit card selection between conventional and Islamic credit cards customers were not significant different. Both of them select the credit cards due to its protection, financing, promotion, and travel economics. However, there were some sub factors that were significant different between the two such as follows: (1) Convenience factor, which are: (a) wide acceptance abroad; and (b) internet purchases and online payment; (2) Protection factor, i.e. protection against loss or defects of products purchased using card; (3) Flexibility factor: (a) Automatic payment in full by direct debit from bank account; (b) Zero interest installment facilities; and (c) Facilitates paying bills electronically and access to statement; (4) Reputation factor: (a) Credit card company such as Visa, MasterCard; and (b) Islamic credit card brand name such as Danamon Syariah, BNI Syariah Hasanah Card and CIMB Niaga MasterCard Syariah.

The ability of credit cards to be used in online payment and accepted globally is very important for Islamic rather than the conventional credit card holders. Unlike other users who utilized the credit card for personal purposes, most of the Islamic credit cards holders used the credit card for paying the consumer durable such as furniture, kitchen equipment, computers and flat screen televisions.

Table 5. The Satisfaction Level of Credit Card Holder

\begin{tabular}{lrrc}
\hline \multicolumn{1}{c}{ Satisfaction Level } & \multicolumn{3}{c}{ Percentage } \\
& Overall & CCC & ICC \\
\hline Extremely Dissatisfied & $2.0 \%$ & $2.1 \%$ & - \\
Dissatisfied & $11.8 \%$ & $12.8 \%$ & - \\
Neutral & $33.3 \%$ & $34.0 \%$ & $25.0 \%$ \\
Satisfied & $43.1 \%$ & $40.4 \%$ & $75.0 \%$ \\
Extremely Satisfied & $9.8 \%$ & $10.6 \%$ & - \\
\hline
\end{tabular}

In order to fathom the satisfaction and loyalty of conventional and Islamic credit card, Hussin (2011) used four questions. Those were 'satisfaction level', 'I have no qualms about switching credit card companies due to poor service', 'I will stop using Islamic credit card and start using conventional credit card with lower charges and better offers', and 'Muslims should use Islamic credit cards even if their charges are higher than conventional credit cards'. From the satisfaction level question, it can be asserted that most of respondents were satisfied with both Islamic and conventional credit card. However, there 
Attitudes of Consumers Towards..........

Azman Ismail, Ilyani Ranlan Rose, Rabaah Tudin, Norazryana Mat Dawi

were still a few respondents who were extremely dissatisfied with their conventional credit cards. They usually had more than three conventional credit cards, used the facilites in more than four years, and had salary between one to five million a month.

In terms of loyalty, most of respondents were neutral when they were asked about the possibility to switch to another credit card. However, the percentage of respondents who answered agree (14 percent) and strongly agree (29 percent) were more than those who responded disagree (6 percent) and strongly disagree (12 percent) (See Table 5). The evidence indicated that the credit card customer loyalty was very dependent on the services and facilities provided by the credit card company. It means that the credit card company must provide excellent service to all customers without exception. Moreover, credit card companies must innovate to improve their services so as to make the customers do not switch to another company.

Interestingly, when respondents were asked about the possibility of leaving the Islamic credit cards companies due to poor service, most of them answered neutral and tend to be disagree to switch to another credit card. This finding showed that if conventional credit card consumers became Islamic credit card customers, they will tend to be more loyal. This was because most respondents tend to agree if a Muslim should use an Islamic credit card although the services, prices, and amenities were still not as competitive as conventional credit card. This condition was actually an opportunity for the Islamic credit card company to capture market share of conventional credit cards since most of them were Moslem.

However, in order to increase the loyalty of credit card users, the bank issuers should be required to keep improving the quality of its services. According Kassim et.al (2014) and Azhar and Novilia (2016), the product quality was the significant factor affecting the customers' loyalty. Improvement of appropriate sharia facilities is done at least as provided by conventional credit cards. Thus, the Islamic credit card market not only covers the people who do choose Islamic credit cards because they want to actually transact sharia, but also the segment of society who do not care about sharia aspect and just want to transact easily and quickly using credit card.

There were ten statements used in capturing the perception of Islamic credit card. Generaly, all respondents considered that the Islamic credit card brought the disrepute more than the kindness. It was apparent from the answers of the respondents agreed that: (1) Islamic credit card concept was not acceptable; (2) Islamic credit cards involved riba; (3) 
Islamic credit cards were against the justice aspect of Islamic financial transactions; (4) Islamic credit card encouraged people to consume more than they need; (5) Islamic credit cards created money and credit; (6) Islamic credit cards lead to debt-based system; (7) The use of Islamic credit card motives/factors to attract Muslims to use the card was unacceptable; (8) Islamic credit card provided convenience; (9) Islamic credit cards were in line with Islamic philosophy; and (10) Islamic credit card encouraged Muslims who did not need credit cards to possess the cards. (See Table 6 for details)

Table 6. Perceptions towards Islamic Credit Cards

\begin{tabular}{|c|c|c|c|c|c|c|c|}
\hline \multirow{2}{*}{ No } & \multirow{2}{*}{ Indicators } & \multicolumn{3}{|c|}{ Mean } & \multicolumn{3}{|c|}{$\begin{array}{l}\text { T-test for equality of } \\
\text { means }\end{array}$} \\
\hline & & Overall & CCC & ICC & t-test & df & sig \\
\hline 1 & $\begin{array}{l}\text { Islamic credit card concept is } \\
\text { acceptable }\end{array}$ & 2.90 & 3.00 & 1.75 & 3.94 & 2.31 & $0.00^{*}$ \\
\hline 2 & Islamic credit cards involve riba & 3.45 & 3.53 & 2.50 & 3.06 & 2.45 & $0.02 *$ \\
\hline 3 & $\begin{array}{l}\text { Islamic credit cards are against } \\
\text { the justice aspect of Islamic } \\
\text { financial transactions }\end{array}$ & 3.22 & 3.30 & 2.25 & 3.47 & 2.45 & $0.01^{*}$ \\
\hline 4 & $\begin{array}{l}\text { Islamic credit card encourages } \\
\text { people to consume more than } \\
\text { they need }\end{array}$ & 3.35 & 3.43 & 2.50 & 1.73 & 2.78 & 0.16 \\
\hline 5 & $\begin{array}{l}\text { Islamic credit cards create money } \\
\text { and credit }\end{array}$ & 3.59 & 3.60 & 3.50 & 0.29 & 2.57 & 0.79 \\
\hline 6 & $\begin{array}{l}\text { Islamic credit cards lead to debt- } \\
\text { based system }\end{array}$ & 3.61 & 3.66 & 3.00 & 1.51 & 2.78 & 0.21 \\
\hline 7 & $\begin{array}{l}\text { The use of Islamic credit card } \\
\text { motives/factors to attract } \\
\text { Muslims to use the card is } \\
\text { unacceptable }\end{array}$ & 3.39 & 3.45 & 2.75 & 2.28 & 2.36 & $0.06^{*}$ \\
\hline 8 & $\begin{array}{l}\text { Islamic credit card provides } \\
\text { convenience }\end{array}$ & 3.43 & 3.38 & 4.00 & $(4.01)$ & 2.01 & $0.00^{*}$ \\
\hline 9 & $\begin{array}{l}\text { Islamic credit cards are in line } \\
\text { with Islamic philosophy }\end{array}$ & 2.96 & 2.94 & 3.25 & $(1.07)$ & 2.45 & 0.33 \\
\hline 10 & $\begin{array}{l}\text { Islamic credit card encourages } \\
\text { Muslims who do not need credit } \\
\text { cards to possess the cards }\end{array}$ & 3.22 & 3.28 & 2.50 & 1.47 & 2.78 & 0.22 \\
\hline
\end{tabular}

Seeing the answers of the respondents overall assumed that the Islamic credit card was almost no difference with conventional credit cards, then maybe this was due to several things. First, the consumer might not understand the basic concepts of Islamic credit cards so that they assumed the same as a conventional credit card. Therefore, it was necessary to educate people related to the basic principles of Islamic credit card system. Second, the Islamic credit card companies should also be cautious in marketing their products, not to provoke consumers to increasingly consumerist behavior which 
Attitudes of Consumers Towards..........

Azman Ismail, Ilyani Ranlan Rose, Rabaah Tudin, Norazryana Mat Dawi

incidentally was not in accordance with shariah. This results were different with Amin (2012) who utilized TRA model to identify factors determining the Malaysian bank customer's behavioral intention to use the Islamic credit card. In that study, the result reveals that attitude, subjective norm and perceived financial cost significantly influence the Islamic credit card intention to use.

The community was still not too clear about the difference usury with the profits derived from the principles of shariah. This was evident from the survey results that show that people still thaught the Islamic credit cards still contained elements of usury. The synergy between academics, scholars, and practitioners of shariah economy was needed to understand the community regarding usury. In addition, education about the concept of Islamic economics was also absolutely necessary so that people did not get caught up in the economic system of usury (Sardiana, 2016).

\section{CONCLUSION}

This study aims to analyze the attitudes of consumers toward Islamic and conventional credit cards in Indonesia through taking a case study in Surabaya. Overall, the respondents possessed the credit cards due to the convenience factor, relationship with the existing bank, and card salesmen. Most of the respondents chosed the type of credit card because of the vigorous and interesting promotion, the existence of tempting travel facilities, the ease and comfort in transacting, and the existence of additional facilities such as insurance that can be accepted in many countries. Unfortunately, the character of credit card customers was less loyal. Their loyalty level was highly dependent on the factors that influence the respondents in choosing the type of credit card.

In order to compare the attitudes between Islamic and conventional credit card, the interesting findings showed that most of consumers choose the Islamic credit cards because of the promotion and the traveling needs. Therefore, since there are no much significant different of the reasons to utilize the credit card, in case of Islamic credit card, it is very necesaary to promote it massively if they want to increase their penetration. However, the Islamic credit card customers were more loyal than the conventional credit card owners. The loyalty of Islamic credit card customers seems to be a strength in itself to expand the reach of the market. Therefore, Islamic credit card issuing banks should be more eager in offering their products and of course improving the quality of service so as not to lose out with the offerings on conventional credit cards. In addition to the ongoing 
promotion, Islamic credit card businesses should also educate the public about the fundamental differences between conventional and Islamic credit cards. This is because until now people are still confused about the urgency of Islamic credit cards and even most respondents assume that the presence of Islamic credit cards will also bring adverse impact on their financial management if cardholders can not be wise in shopping.

\section{ACKNOWLEDGE}

This work was supported by Faculty of Economics and Business, Universitas Airlangga research grants.

\section{REFERENCES}

Abduh, M., \& Omar, A. (2010). Who Patronises Islamic Banks in Indonesia? Australian Journal of Islamic Law, Management and Finance. 1 (1): 40-53.

Ali, M., \& Raza, S.A. (2015). Factors affecting to select Islamic Credit Cards in Pakistan: The TRA Model. MPRA Paper No. 64037, posted 2. May 2015 06:54 UTC

Amin, H. (2012), "Factors influencing Malaysian bank customers to choose Islamic credit cards Empirical evidence from the TRA model", Journal of Islamic Marketing, Vol. 4 No. 3, pp. 245-263

Azhar, A., \& Novilia, N. (2016). Determinant of Nokia's Users Loyalties (Case Study on Societies of Air Simpang Village, Ketahun Subdistrict, Bengkulu Utara. Etikonomi. 15 (1): 63-74.

Choo S Y, Lim H E, \& Sanusi N A (2007). The Consumer Choice of Islamic-based Credit Card: an Analysis of Bivariate Probit Model. In. Sanusi, N.A., Harun, M. and Samsudin, S. (eds). Readings in Islamic Economics and Finance, Sintok: Universiti Utara Malaysia Press.

Dali, N. R. S., Abdul-Hamid, H., Shahimi, S. \& Wahid, H. (2008). Factors Influencing The Islamic Credit Cards Holders Satisfaction. The Business Review. 11 (2): 298-304.

Dali N.R.S. (2014). Islamic Credit Card User's Satisfaction: A Comparative Study. (Unpublished Dissertation). Cardiff: Cardiff University, UK.

Ferdian, I. R., Dewi, M. K., \& Rahman, F. K. (2008). The Practice of Islamic Credit Cards: A Comparative Look between Bank Danamon Indonesia's Dirham Card and Bank Islam Malaysia's BI Card. Proceeding of LAEI International Conference, Surabaya, Indonesia, 1-3 August 2008.

Hanudin, A. (2012). Explaining Intention to Use the Islamic Credit Card: an Extension of The TRA Model. MPRA Paper No. 36957, posted 26. February 2012 20:42 UTC 
Attitudes of Consumers Towards

Azman Ismail, Ilyani Ranlan Rose, Rabaah Tudin, Norazryana Mat Dawi

Kassim, A.W.M. et.al (2014). Mediating Effect of Customer Satisfaction on Perceived Product Quality, Perceived Value and Their Relation to Brand Loyalty. International Journal of Management and Business Studies. 1 (2): 13-18.

Luarn, P. \& Lin, H.H. (2005). Toward an Understanding of The Behavioural Intention to Use Mobile Banking. Computer in Human Behaviour. 21 (6): 873-891.

Mansor, N. \& Che-Mat. A. (2009). Islamic Credit Card: are Demographic Factors a Good Indicator. Asian Social Science. 5 (12): 17-26.

Mathieson, K., Peacock, E. \& Chin, W.W. (2001). Extending the technology acceptance model: the influence of perceived user resources. DATABASE for Advance in InformationSystem. 32 (3): 86-112.

Ramayah, T., Jantan, M., Noor M.N.M., \& Ling K.P (2003). Receptiveness of internet banking by Malaysian consumers. Asian Academy of Management Journal. 8(2):1-29.

Ramayah, T., \& Mohd-Suki, N.M. (2006). Intention to Use Mobile PC among MBA Students: Implications for Technology Integration in The Learning Curriculum. UNITAR e-J. 1(2):1-10.

Sardiana, A. (2016). The Impact of Literacy to Shariah Financial Service Preference. Etikonomi. 15 (1): 43-62.

Yee, C.S., Eam, L.H. \& Sanusi, N.A. (2007). The Consumer Choice of Islamic-based Credit Card: an Analysis of Bivariate Probit Model. in Sanusi, N.A., Harun, M. and Samsudin, S. (Eds), Readings in Islamic Economics and Finance. Sintok: Universiti Utara Malaysia Press. 